\title{
Determining Pre-Service Teachers' Intention of Using Technology for Teaching English as a Second Language (ESL)
}

\author{
Lim Lai Wah and Harwati Hashim *(D) \\ Faculty of Education, Universiti Kebangsaan Malaysia, Bangi 43600, Malaysia; lyralimlaiwah@gmail.com \\ * Correspondence: harwati@ukm.edu.my
}

Citation: Lai Wah, L.; Hashim, H. Determining Pre-Service Teachers' Intention of Using Technology for Teaching English as a Second Language (ESL). Sustainability 2021, 13, 7568. https://doi.org/10.3390/ su13147568

Academic Editors: Dunja Anđić, Nena Rončević and Michele Biasutti

Received: 3 June 2021

Accepted: 2 July 2021

Published: 6 July 2021

Publisher's Note: MDPI stays neutral with regard to jurisdictional claims in published maps and institutional affiliations.

Copyright: (c) 2021 by the authors. Licensee MDPI, Basel, Switzerland. This article is an open access article distributed under the terms and conditions of the Creative Commons Attribution (CC BY) license (https:/ / creativecommons.org/licenses/by/ $4.0 /)$.

\begin{abstract}
The advancement of technology has led to a paradigm shift in the educational system, especially in classrooms. Technological tools have been used for language teaching in recent years, and it is proven that the use of technology enhances teaching and learning experiences. However, the researchers lamented the lack of use of technology by pre-service to teach English as a second language (ESL). This study aims to investigate factors that influence pre-service teachers' intention of using technology for teaching ESL. This research applied the Unified Theory of Acceptance and Use of Technology (UTAUT) with some modifications to the constructs. Using simple random sampling, this study distributed questionnaires to 257 ESL pre-service teachers in Malaysia. Confirmatory factor analysis (CFA) and structural equation modelling (SEM) were used to analyse the data. The findings showed that technological, pedagogical, and content knowledge (TPACK) had a significant positive effect on the intention to incorporate technology in teaching. This study provides knowledge on the factors that influence ESL pre-service teachers' intention to use technology in the classroom. It is hoped that this study can provide information for teacher training institutions to develop strategies and a new framework to address pre-service teachers' concerns in technology utilisation for teaching ESL. As a conclusion, further study could be conducted qualitatively to better understand the subject matter.
\end{abstract}

Keywords: utilisation of technology; pre-service teachers; English as a second language (ESL) classroom; unified theory of acceptance and use of technology (UTAUT)

\section{Introduction}

One of the most significant changes in education over the past decades is the integration of technology. The use of technology in education has changed the teaching and learning manner. According to [1], it is important to note that technology has been used in language teaching for decades. Tape recorders, language labs, and videos have been used in classrooms around the world since the 1960s and 1970s [2]. In the 1980s and 1990s, there was a shift in the trend of language teaching, which emphasised the authenticity of materials and meaningful interaction [3]. With that, the integration of technology in classrooms has become increasingly important.

The use of technology in education is undeniably essential. This is because there are still a large number of researchers who believe that technology is a cognitive tool and instructional media, despite debates on the effectiveness of technology [4]. According to $[4,5]$, technology can encourage inquiry, promote communication, construct teaching products, and assist students' self-expression. With that, it helps students to have a better learning experience. Knowing its importance, the Malaysian education system has also shown a shift. Leading-edge technology is used to transform memory-based schooling culture to informing, thinking, creativity, and caring [6].

A paradigm shift in English lessons in Malaysia has been created by the myriad emergence of technologies. This is because the chalk and talk teaching method is insufficient to teach English effectively [7]. Thus, technology has become a tool to support English 
language learning. This was proven through a study done by [8] on using the WhatsApp application in English dialogue journals, with the findings of the study revealing that learners have an improvement in their writing and speaking skills, vocabulary, and word choice as a result of the use of WhatsApp. According to [9], English language learners can also improve their English language proficiency through online English language learning websites, computer-assisted language learning programmes, presentation software, electronic dictionaries, chatting and email messaging programmes, listening to $C D$ players, and learning through video clips. On the basis of the findings of past research, researchers found that learners' standard of English is able to be enhanced through the use of technology in classrooms. Therefore, the utilisation of technology in ESL classrooms has become increasingly important.

Due to the importance of technology in education, English teachers nowadays are required to be techno-savvy as they have to incorporate technology in their English as Second Language (ESL) classrooms. However, in reality, the use of technology is often disregarded in teacher training programmes [1]. Hence, although teachers are aware of the importance of the use of technology, the utilisation of technology has yet to reach expectation [10]. As there is insufficient use of technology among teachers in classrooms, there have been studies performed in the past to find out the factors that affect the utilisation of technology in classrooms. However, most of the past studies focused on foreign context and in-service teachers. Pre-service teachers were often overlooked by most researchers.

Therefore, the purpose of this study was to identify the factors that affect Malaysian pre-service teachers' use of technology in the ESL classroom. Moreover, this study aimed to find out the most influential factors that affect the use of technology in ESL classrooms among pre-service teachers. This was to gain a better understanding of the teaching and learning situation. A quantitative instrument was employed in this study. Data were gathered through a survey with pre-service teachers regarding the factors that affect the use of technology. An overview is provided on the basis of the general findings of the survey.

\section{Literature Review}

The presence of technologies in today's world has expanded dramatically. There is a worldwide expansion of technologies into many aspects of social life, significantly in the last three decades [11]. It is crucial for pre-service teachers and in-service teachers to be technology savvy since the governments in most parts of the world intend to prepare children nowadays for the information age. Therefore, there is technology in education. According to [12], educational technology is creating, using, and managing ICT facilities to promote learning by allowing free access to information. The use of print, film, and internet enable learners to have access to a range of information, and this offers students a wide range of materials for interpretation of language and contexts [13].

The importance of technology in education is further proven by [14], who conducted a study to investigate if Wiki technology helps in enhancing learners writing skills; the results revealed the reading of their peers' writings helps to boost learners' mastery of vocabulary, spelling, and sentence structure. Moreover, the use of technology can also improve learners' reading skills. This is supported by a study conducted by [15] on how the use of technology increases university students' English reading ability, and the findings revealed that their reading skills have improved through the digital reading web. Other than that, the use of technology can improve learners speaking skills. The findings of a study proved that Skype conference call is a supporting tool that can enhance learners' English-speaking skills, mainly in the aspects of social interaction, language fluency, and course contents outside the classrooms [16]. Aside from that, incorporating technology in education helps in terms of motivation. Learners are more likely to engage in lessons when there is an integration of technology as an education tool $[17,18]$. In other words, the use of technology in ESL classrooms benefits learners in learning the English language.

With that, teachers are anticipated to use technology in their lessons. As a result, most of the teacher training programmes have a technology training component [11]. However, 
most past studies on the level of technology use by pre-service teachers found that preservice teachers are unlikely to use technology in their lessons [19]. The under-use of technology in lessons among pre-service teachers is the result of ineffective technology teacher training programmes. This is supported by the findings of a study conducted by [20] because the respondents also claimed that teacher education courses have not prepared the teachers for the use of modern technologies, and therefore they proposed that there should be more importance given to the utilisation of technology to enhance language skills. The authors of [21] also shared the same perception as they believe that the under-use of technology in classrooms may be due to the failure to equip pre-service teachers with both technological skills and the technique to incorporate technology in the curriculum, instead of merely technology knowledge. The authors of [22] followed suit, and they proposed the technological, pedagogical, and content knowledge (TCPK), which takes into account how content, pedagogy, and technology dynamically constrain each other, helping teachers to utilise technology in classrooms more effectively. In other words, teachers have to possess content, pedagogy, and technology knowledge to be able to successfully deliver their lessons.

On other hand, there is a claim that those pre-service teachers who utilise technology in their lessons are mostly driven by their self-efficacy [19]. However, the authors of [23] argued that there are other intentions that may urge teachers in the use of technology in classrooms, and therefore they proposed the Unified Theory of Acceptance and Use of Technology (UTAUT) that stated performance expectancy, effort expectancy, and social influence affect behavioural intention to use technology, which the behavioural intention and facilitation conditions determine technology use. Despite that, the findings of a study conducted by [4] discovered that there is a difference between theoretical belief and realworld contexts, because the findings of their study revealed that, in reality, the influential factors that affect teachers' use of technology in the classroom are adapting the external requests and other expectations; deriving attention; using the basic functions of technology; relieving physical fatigue, class preparation, and management; and using the enhanced functions of technology.

There are many challenges faced by teachers in the use of technology in the classroom, which affects their integration of technology in the classroom [24-26]. The abundance of technology, which leads to a hassle in choosing technology to be integrated in lessons, and for being time-consuming, especially in setting up, are reported to be challenges in teachers' integration of technology in the classroom. This is more apparent among pre-service teachers, as research findings suggest that pre-service teachers are not fully ready for technology integration in education. As a result, most past studies on pre-service teachers' technology utilisation are to find out how much teacher education programmes prepare teachers in terms of the integration of technology in their teaching [27]. However, there were some studies that focused on whether pre-service teachers are able to apply the skills and knowledge that they have learned from technology training programmes during their college into real teaching [28]. Given the lack of comprehensive study on this matter, it is of great importance to examine the factors that affect technology utilisation of pre-service teachers [29].

A number of challenges faced by pre-service teachers in technology integration have been identified. Limited access of technological devices, inability to apply pedagogical knowledge learned in real life teaching experience, and lack of experience in the use of technological tools are some of the challenges that the pre-service teachers face $[30,31]$. There is no doubt that these are the factors that lead to the lack of technology integration, but findings of a study conducted by [32] in 2016 highlighted that attitudes and beliefs of pre-service teachers are other barriers that affect their utilisation of technology. In another research work, the findings suggested that performance expectancy, effort expectancy, and social influence were the determinants of pre-service teachers' intention of using technology $[33,34]$. In a similar study, the findings showed that performance expectancy, facilitating condition, and attitude significantly influence a teacher's intention of using 
technology [35]. Pre-service teachers' level of technology acceptance also has a significant impact on their integration of technology in the classroom [36]. For this reason, there were many past studies on the factors that influence pre- service teachers' technology acceptance.

Moreover, in the last decade, technological, pedagogical, and content knowledge (TPACK) is accepted as a framework that is related to teachers' technology integration in their classrooms [37]. It is a seven-component model that shows the link between technology knowledge (TK), pedagogical knowledge (PK), and content knowledge (CK). In other words, it refers to the pedagogical way of knowing how to teach content with the use of the most appropriate technology [38]. To address some of the common barriers in the integration of technology in classrooms, substantial funds have been allocated for the usage of technology in Malaysian education, including the building of computer labs, supplying of PCs and related peripherals, training of teachers, and development of instructional materials [39]. With that, some teachers do attempt to incorporate technology in their teaching. However, there are some who do not make use of multimedia tools, despite knowing their great capability in providing assistance to enhance teaching [40]. The method and mode to use technology in ESL classrooms are often missing [41].

Although many studies have been conducted to understand pre-service teachers' technology integration, there are still some obstacles that affect pre-service teachers' use of technology in the ESL classroom. Therefore, to address the gap, this study intended to identify factors the factors that affect ESL pre-service teachers' utilisation of technology in classrooms and to determine the extent of its incorporation in Malaysian English language classrooms among pre-service teachers.

\section{Methodology}

A descriptive survey design was used in this quantitative study. This study was conducted due to the unsatisfactory pre-service teachers' use of technology in ESL classrooms. Due to this fact, this study intended to explore factors that affect pre-service teachers' use of technology in Malaysian ESL classrooms.

Convenient sampling was used for this study because it was inexpensive and the respondents were readily available. Prior to that, the researcher communicated with some pre-service teachers (samples) to set a good ground and platform to promote a good rapport and ideal relationship built to gain cooperation and conduct the survey successfully without any obstacles, which is common in the process of collecting raw data. A total number of 100 undergraduate TESL students participated in this study. These 100 samples were randomly chosen, as a large sample ensures validity and reliability of the study. A total of $81 \%$ of the participants were females, and $19 \%$ were males. The majority of them were at the age of 18 to 21 , which accounts for $65 \%$.

The survey method was followed to collect the data on the factors that affect the utilisation of technology in ESL classrooms among pre-service teachers. A questionnaire was designed to gather sufficient information pertaining to the objective of the study. In order to ensure the validity of the questionnaire, we obtained experts' feedback and conducted face validity and content validity. A pilot test was also conducted to test the reliability of the instrument. The coefficient value for all constructs ranged from 0.795 to 0.858 , which was higher than the acceptable limit. The authors of [42] suggested that a value of 0.6 to 0.7 is acceptable, while 0.8 or greater is very ideal. In this study, the coefficient value for performance expectancy was 0.803 , the coefficient value for effort expectancy was 0.795 , the coefficient value for facilitating condition was 0.858 , the coefficient value for deriving attention was 0.813 , and the coefficient value for intention was 0.822 . All values are well above the recommended value.

Questionnaires were distributed to the respondents for data collection. As it is a web-based survey, the questionnaire was distributed to the respondents through Google Form. This promotes convenience to researchers and respondents as they could answer the questionnaire through their electronic gadgets no matter where they were. There are two sections in the questionnaire, which are demographic factors and the factors that affect 
pre-service teachers' use of technology in the ESL classroom. There were 5 demographic questions and 35 questions on factors of utilisation of technology. Pre-service teachers had to rate the items that indicate factors that affect their use of technology in ESL classrooms in the questionnaire on the basis of their level of agreement or disagreement. They were on a five-point Likert scale ranging from 1 (strongly disagree) to 5 (strongly agree). Cronbach alpha was used to determine the reliability of the questionnaire, and it was 0.951 . The value indicated a high level of reliability.

In order to answer the research questions, we analysed the gathered data using Structural Equation Modelling Software (SEM). This study used this family of statistical models because it explains the relationship between multiple variables. In order to test the theoretical models, we conducted a two-step procedure that consisted of the measurement model, confirmatory factor analysis (CFA), and structural model. CFA was performed to evaluate the contribution of each item (indicator variable) to the construct (latent variables) being assessed, while the structural model was performed to determine the strength of the hypothesised relationship between the constructs. The following are the hypotheses tested in this study:

Hypothesis 1 (H1). Performance expectancy has a significant effect on TESL pre-service teachers' use of technology for teaching ESL.

Hypothesis 2 (H2). Effort expectancy has a significant effect on TESL pre-service teachers' use of technology for teaching ESL.

Hypothesis 3 (H3). Facilitating condition has a significant effect on TESL pre-service teachers' use of technology for teaching ESL.

Hypothesis 4 (H4). Technological, pedagogical, and content knowledge (TPACK) has a significant effect on TESL pre-service teachers' use of technology for teaching ESL.

\section{Findings}

\subsection{Measurement Models}

The more efficient and highly suggested method for assessing the measurement model is to combine all latent construct (pooled) in one measurement model. The measurement model is assessed and validated using confirmatory factor analysis (CFA). This method is called pooled CFA. In the pooled CFA, the item deletion process is made for every construct by selecting the items with the lowest factor loading in each construct to be deleted. The CFA results showing fitness indexes and factor loading for every item together with its $R^{2}$ are presented in Figure 1. Using this method, we computed the correlations between constructs simultaneously.

As shown in Figure 1, certain factor indexes for the pooled constructs did not achieve the required level, which was greater and equal to 0.6 . Table 1 presents the summary of the fit statistics for the initial model.

Table 1. Summary of fit statistics for initial model.

\begin{tabular}{ccccc}
\hline Name of Index Category & Name of Index & Index Value & Level of Acceptance & Comments \\
\hline Absolute fit & RMSEA & 0.091 & RMSEA 0.05 to 0.10 & The required level is achieved \\
\hline Incremental fit & CFI & 0.813 & CFI $>0.90$ & The required level is not achieved \\
\hline Parsimonious fit & ChiSq/df & 2.960 & ChiSq $/ \mathrm{df}<3.0$ & The required level is achieved \\
\hline
\end{tabular}

On the basis of the data displayed in Table 1, we found that two of the index categories obtained, which were absolute fit (RMSEA) and parsimonious fit (ChiSq/df), had achieved the required level. However, the model did not fit the incremental index category (CFI) where the index value was 0.813 below the required level. Item with factor loading below 
0.60 was identified. Therefore, the item that was below 0.6 was deleted. The fitness indexes were examined every time the new measurement was run after an item is deleted. The fitness indexes were examined every time the new measurement was run until the fitness indexes were achieved. In this procedure, item pe4, ee7, tpack7, tpack8, tpack9, i4, i5, and i6 were found to have low factor loading as compared to the other items. Finally, the new measurement model was run, as shown in Figure 2.

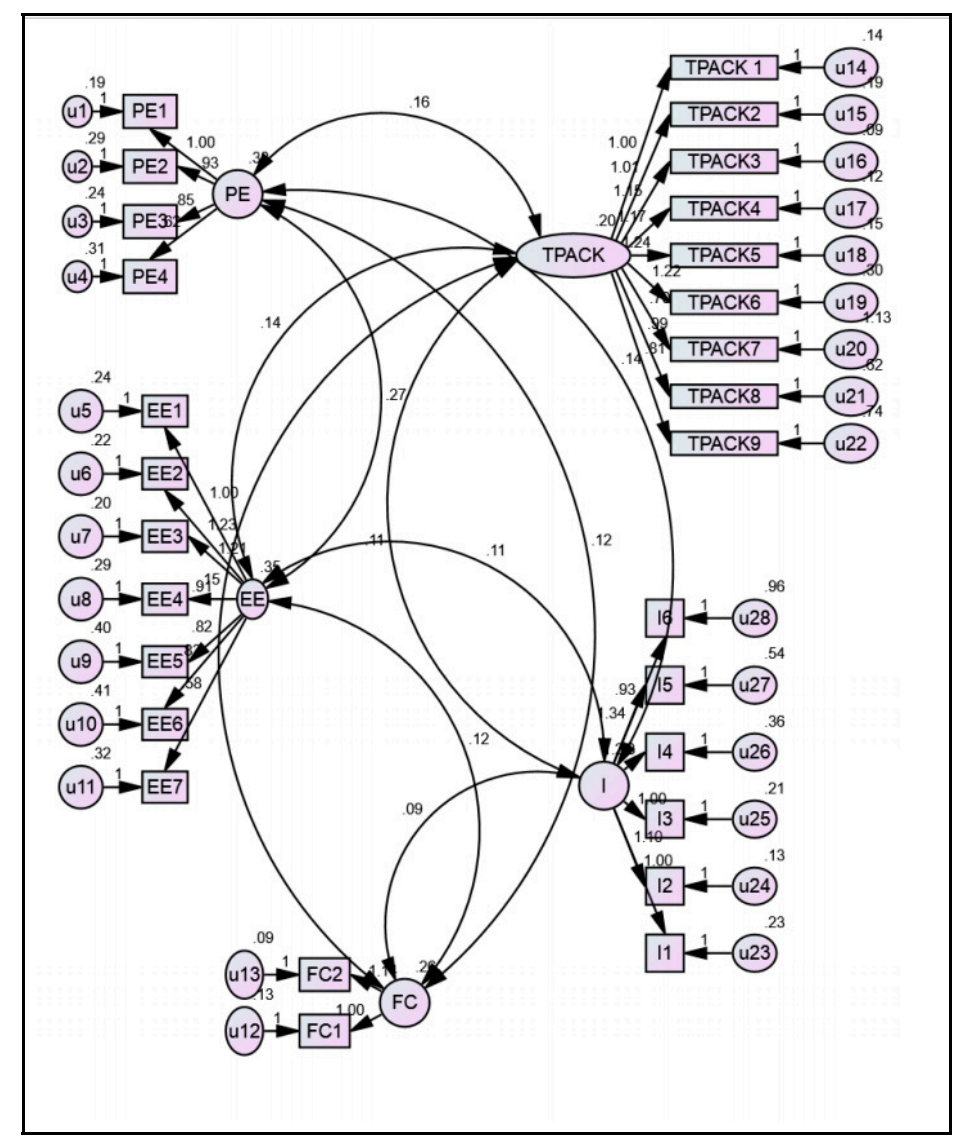

Figure 1. The factor loading for all items of the respective constructs.

After the CFA procedure, the fitness indexes for the model were assessed on the basis of the results in Table 2.

Table 2. Summary of fit statistics for new measurement model.

\begin{tabular}{ccccc}
\hline Name of Index Category & Name of Index & Index Value & Level of Acceptance & Comments \\
\hline Absolute fit & RMSEA & 0.062 & RMSEA 0.05 to 0.10 & The required level is achieved \\
\hline Incremental fit & CFI & 0.945 & CFI $>0.90$ & The required level is achieved \\
\hline Parsimonious fit & ChiSq/df & 1.915 & ChiSq $/ \mathrm{df}<3.0$ & The required level is achieved \\
\hline
\end{tabular}

On the basis of the data displayed in Table 2, we found that all three index categories obtained had achieved the required level. For absolute fit index category, index value for RMSEA was 0.062, which had achieved the required level. For incremental fit index category, the CFI index value was 0.945 , which had achieved the required level, as well as the parsimonious fit category, where the index value for ChiSq/df was 1.915 and had also achieved the required level. Hence, the model was judged to have an acceptable fit. 


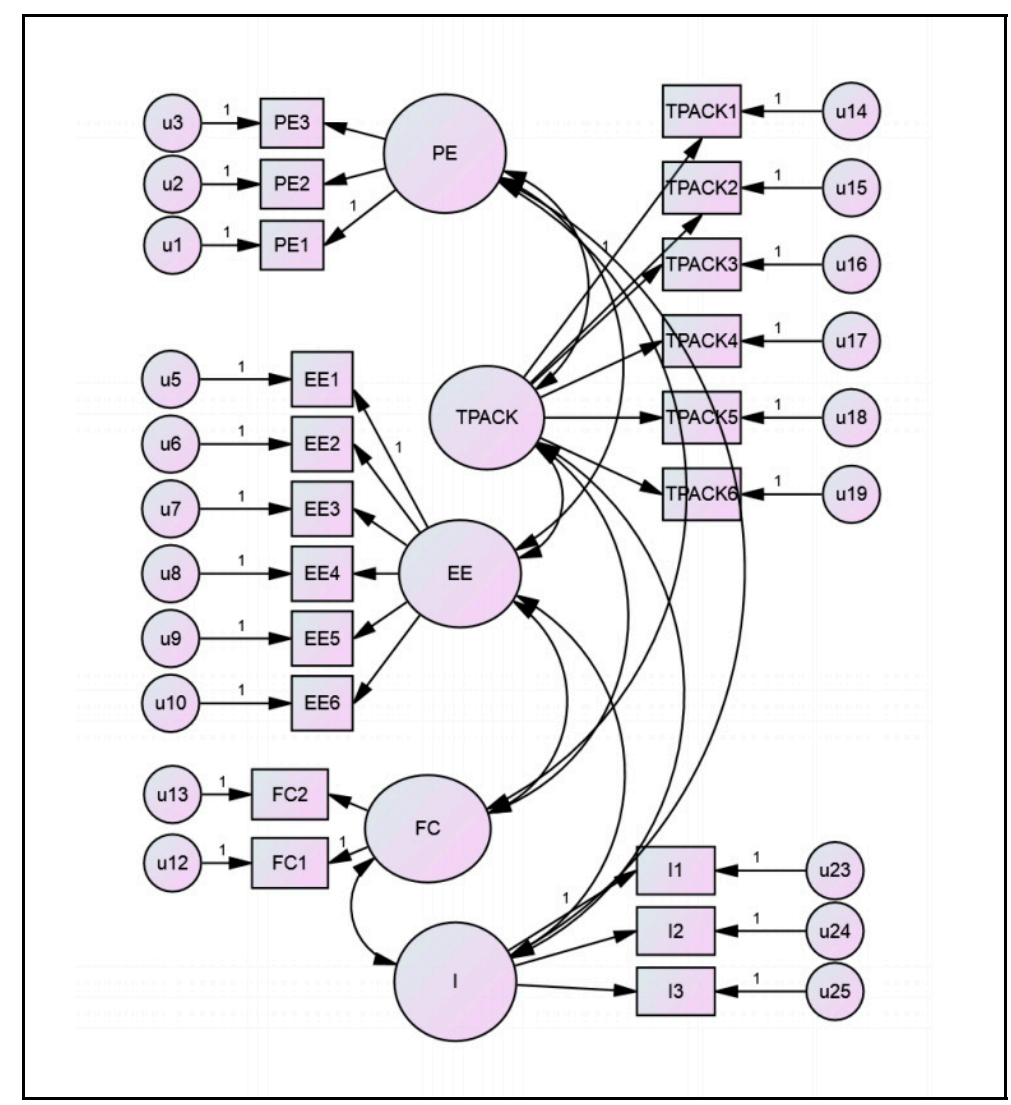

Figure 2. Final measurement model after CFA procedure.

\subsection{The Structural Equation Modelling}

The constructs were analysed in one full structural model by using structural equation modelling (SEM). In SEM, the multiple relationships among the constructs are analysed simultaneously. The standardised estimate for the model is presented in Figure 3, while the corresponding fitness indexes and assessment are presented in Tables 3 and 4 .

Table 3. The fitness indexes assessment for the structural model in Figure 3.

\begin{tabular}{ccccc}
\hline Name of Index Category & Name of Index & Index Value & Level of Acceptance & Comments \\
\hline absolute fit & RMSEA & 0.066 & RMSEA 0.05 to 0.10 acceptable & The required level is achieved \\
\hline Incremental fit & CFI & 0.938 & CFI $>0.90$ & The required level is achieved \\
\hline Parsimonious fit & ChiSq/df & 2.030 & ChiSq $/ \mathrm{df}<3.0$ & The required level is achieved \\
\hline
\end{tabular}

Table 4. The standardised regression weight as shown in Figure 3.

\begin{tabular}{cc}
\hline Path & Standardised Beta Estimate \\
\hline $\mathrm{I}<-$ PE & 0.226 \\
\hline $\mathrm{I}<-$ EE & -0.003 \\
\hline $\mathrm{I}<-$ FC & 0.101 \\
\hline $\mathrm{I}<-$ TPACK & 0.363 \\
\hline
\end{tabular}




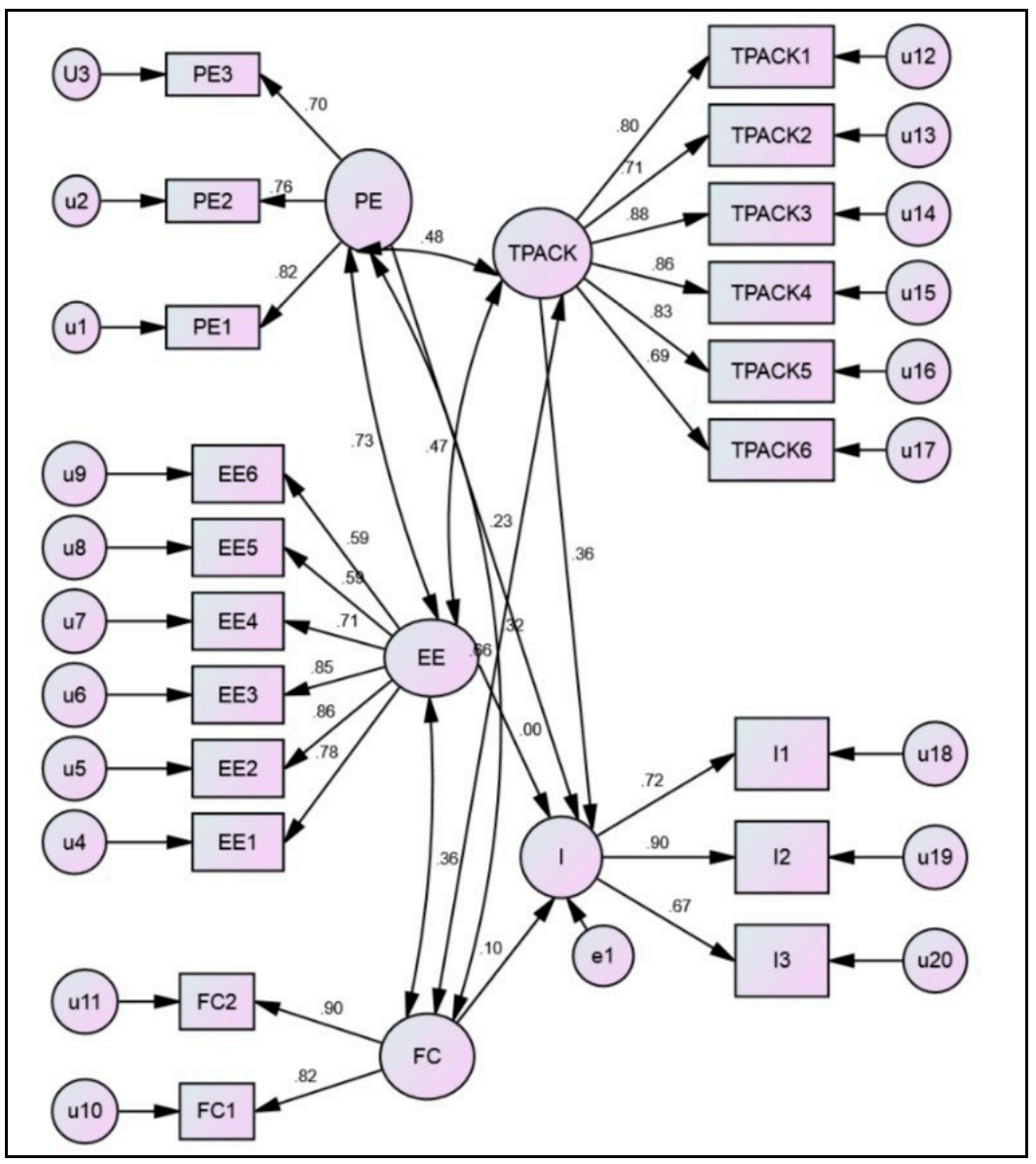

Figure 3. The standardised path coefficient for the model.

On the basis of the data displayed in Table 3, we found that all three index categories achieved the required level. For absolute fit index category, index value for RMSEA was 0.066, which had achieved the required level. For incremental for fit index category, the CFI index value was 0.938, which had achieved the required level, as well as the parsimonious fit category, where the index value for Chisq/df was 2.030 and had also achieved the required level. Hence, the model was judged to have an acceptable fit.

The output in Figure 3 indicates that Malaysian TESL undergraduates' use of technology in the ESL classrooms could be measured by using performance expectancy; effort expectancy; social influence; facilitating conditions; technological, pedagogical, and content knowledge (TPACK); and intention. The standardised beta estimates are as shown in Table 4.

As shown in Table 4, the standardised beta estimate for performance expectancy was 0.226 , standardised beta estimate for effort expectancy was -0.003 , standardised beta estimate for facilitating condition was 0.101 , while the standardised beta estimate for TPACK was 0.363 . Each path coefficient was also checked to verify whether it was statistically significant or otherwise. Figure 4 displays the path coefficient for the model, while Table 5 presents the regression path coefficient results and its significance. 


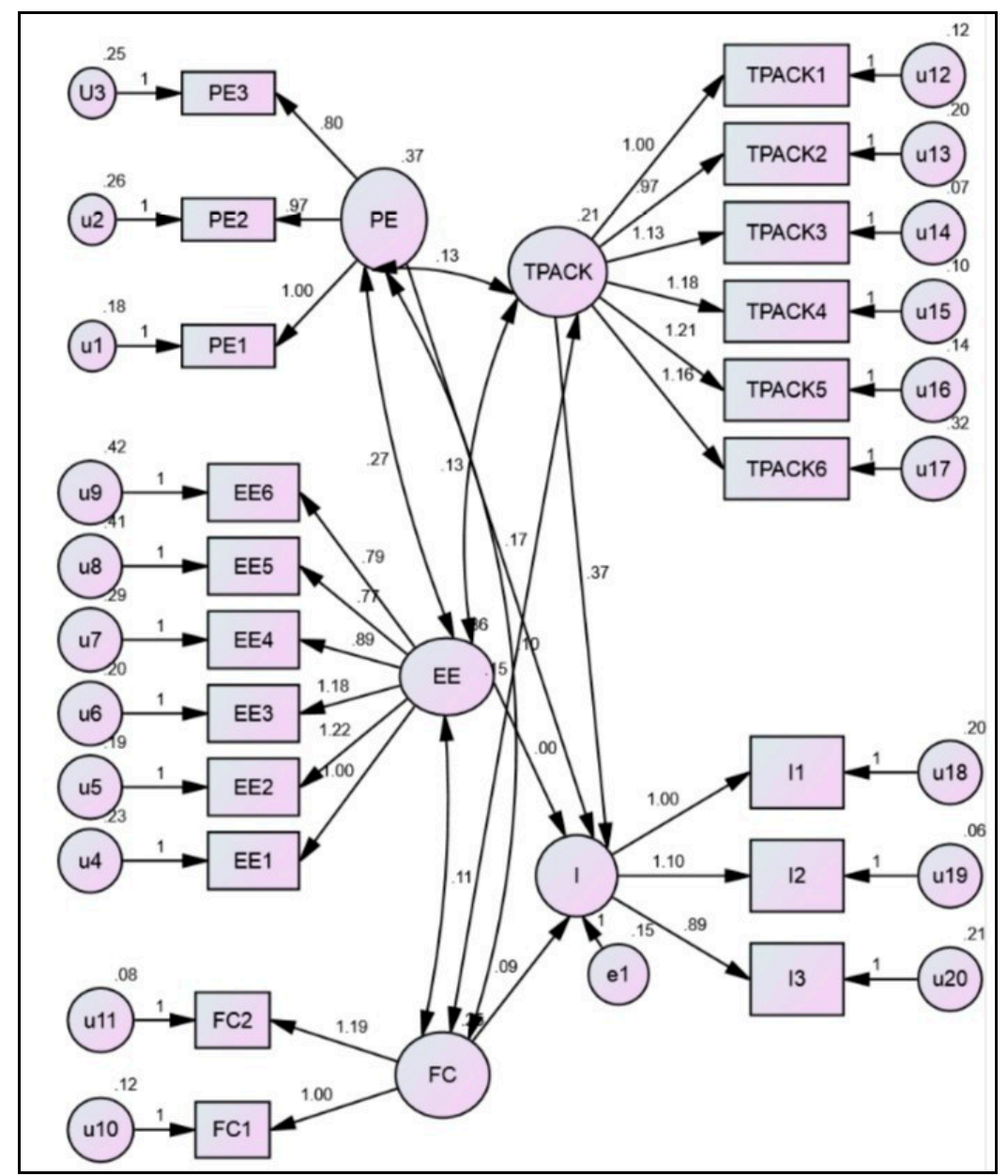

Figure 4. The regression path coefficient for the model.

Table 5. The regression path coefficient and its significance.

\begin{tabular}{cllcccccc}
\hline & Path & & Estimate & S.E. & C.R. & $p$ & Result \\
\hline I & $<-$ & PE & 0.174 & 0.092 & 1.891 & 0.059 & Not significant \\
\hline I & $<-$ & EE & -0.003 & 0.086 & -0.029 & 0.976 & Not significant \\
\hline I & $<-$ & FC & 0.094 & 0.088 & 1.062 & 0.288 & Not significant \\
\hline I & $<-$ & TPACK & 0.372 & 0.108 & 3.458 & $<0.01$ & Significant at 0.10 \\
\hline
\end{tabular}

The results presented in Table 5 indicate that only technological and pedagogical knowledge construct have a significant effect on the Malaysian TESL undergraduates' use of technology in the ESL classroom. The analysis shows that the path coefficient between technological and pedagogical knowledge and intention is statistically significant with the regression coefficient of 0.372 . However, the path coefficient between performance expectancy, effort expectancy, and facilitating condition and intention were not statistically significant with the regression coefficient of 0.174 for performance expectancy, -0.003 for effort expectancy, and 0.094 for facilitating condition. Thus, the followings hypotheses are answered:

\section{(1) Performance expectancy}

Hypothesis 1 (H1). Performance expectancy has a significant effect on TESL pre-service teachers' use of technology for teaching ESL. 
For hypothesis 1, the study aimed to investigate the effect of performance expectancy on the Malaysian TESL undergraduates' use of technology in ESL classrooms. Results from SEM of the proposed model revealed that the standardised coefficient for path 'intention <performance expectancy' was 0.226 , while the unstandardised coefficient for path 'intention <-performance expectancy' was 0.174 , indicating that $\mathrm{H} 1$ was rejected at the 0.10 level of significance. The findings show that performance expectancy did not have a significant effect on the Malaysian TESL undergraduates' use of technology for teaching ESL.

\section{(2) Effort expectancy}

Hypothesis 2 (H2). Effort expectancy has a significant effect on TESL pre-service teachers' use of technology for teaching ESL.

For hypothesis 2, the study aimed to investigate the effect of effort expectancy on the Malaysian TESL undergraduates' use of technology in ESL classrooms. Results from SEM of the proposed model revealed that standardised coefficient for path 'intention <- effort expectancy' was -0.003 , while the unstandardised coefficient for path 'intention <- effort expectancy' was -0.003 , indicating that the $\mathrm{H}_{2}$ was rejected at the 0.10 level of significance. The findings show that effort expectancy did not have a significant effect on Malaysian TESL undergraduates' use of technology for teaching ESL.

\section{(3) Facilitating conditions}

Hypothesis 3 (H3). Facilitating condition has a significant effect on TESL pre-service teachers' use of technology for teaching ESL.

For hypothesis 3 , the study aimed to investigate the effect of facilitating conditions on the Malaysian TESL undergraduates' use of technology in ESL classrooms. Results from SEM of the proposed model revealed that standardised coefficient for path 'intention <facilitating condition' was 0.101 , while the unstandardised coefficient for path 'intention $<-$ facilitating condition' was 0.094 , indicating that the $\mathrm{H}_{3}$ was rejected at the 0.10 level of significance. The findings showed that the facilitating condition did not have a significant effect on Malaysian TESL undergraduates' use of technology in ESL classrooms.

(4) Technological, Pedagogical, and Content Knowledge

Hypothesis 4 (H4). Technological, pedagogical, and content knowledge (TPACK) has a significant effect on TESL pre-service teachers' use of technology for teaching ESL.

For hypothesis 4 , the study aimed to investigate the effect of technological and pedagogical knowledge on the Malaysian TESL undergraduates' use of technology in ESL classrooms. Results from SEM of the proposed model revealed that standardised coefficient for path 'intention <- technological and pedagogical knowledge' was 0.363 , while the unstandardised coefficient for path 'intention <- technological, pedagogical, and content knowledge' was 0.094 , indicating that the $\mathrm{H}_{4}$ was accepted at the 0.10 level of significance. The findings show that technological and pedagogical knowledge had a significant effect on Malaysian TESL undergraduates' use of technology for teaching ESL.

\section{Discussion}

The results by structural equation modelling rejected the research hypothesis for the following factors: performance expectancy, effort expectancy, and facilitating conditions. However, the results of the structural equation modelling accepted one research hypothesis, which was for the factor related to technological, pedagogical, and content knowledge (TPACK). Regression coefficient results indicated that technological, pedagogical, and content knowledge (TPACK) is the only significant predictor of Malaysian pre-service teachers' intention for using technology in ESL classrooms.

The final model linking the construct, technological, pedagogical, and content knowledge (TPACK) was then verified through the test of the proposed model. Referring to 
Figure 5, the final model suggests that technological, pedagogical, and content knowledge (TPACK) had a significant effect on Malaysian ESL pre-service teachers' intention towards the use of technology for teaching ESL.

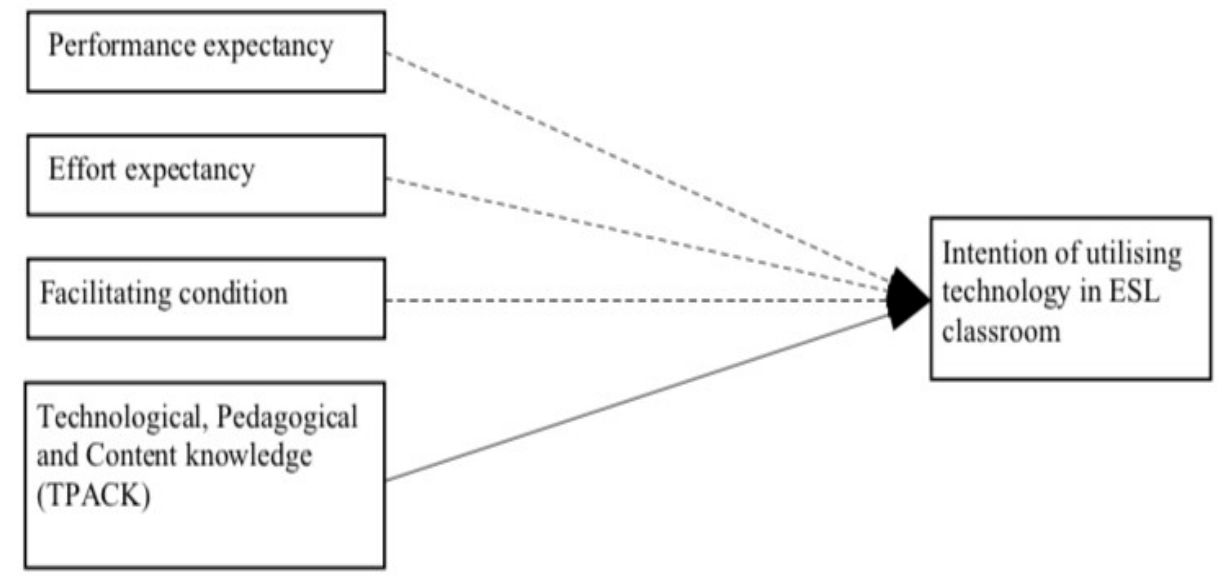

Figure 5. The final model of the study.

The results indicate that the proposed conceptual model may not adequately explain and predict Malaysian English as a second language (ESL) pre-service teachers' intention for using technology in the classroom. This may be due to the inability of the use of the tools at ease, although there is an awareness on the usefulness of the technology as there is a lack of technical support mentioned in the past studies. It is apparent that teachers' technological, pedagogical, and content knowledge (TPACK) plays an important role in the intention of technology utilisation in the classroom. The results show the lack of competence in pedagogical technological tool application, and insufficient knowledge of digital technology teaching approaches are the challenges in the incorporation of technology and in the redesigning of learning tasks. With that, the utmost important competence that a teacher should have for the utilisation of technology is pedagogical skills [40]. However, the authors of [38] also argue that teachers' digital literacy skills are important as the use of technology in the classroom is now an essential instead of a choice, especially during this COVID-19 pandemic that has triggered the new educational context of online learning.

Therefore, it is shown that technological, pedagogical, and content knowledge (TPACK) affect teachers' incorporation of technology in the classroom. For technological, pedagogical, and content knowledge (TPACK), teaching is not to transfer content to anyone, just as learning is not to memorise but to create the possibilities for the production and construction of knowledge. With technological knowledge, one can facilitate pedagogical approaches to support the construction of knowledge, which eventually affects teachers' intention to use technology in the classroom. On the other hand, performance expectancy, effort expectancy, and facilitating conditions do not significantly influence ESL pre-service teachers' use of technology in ESL classrooms because most pre-service teachers at university age are known as digital natives, Generation Y (GenY), Net Generation (Net Gen), and Millennials [40]. Thus, they are better teachers in the use of technology. In other words, all they need is the practice ground of incorporating their technological, pedagogical, and content knowledge (TPACK). On the basis of the hypothesis tests and regression analysis, as shown in Figure 6, we found that performance expectancy, effort expectancy, and facilitating condition will not affect ESL pre-service teachers' use of technology in the classroom, as the only factor that is considered as an important factor impacting ESL pre-service teachers' intention for using technology in classroom is technological, pedagogical, and content knowledge (TPACK). The significant portion of variance in intention for using technology in ESL classroom is $R^{2}=0.334$. 


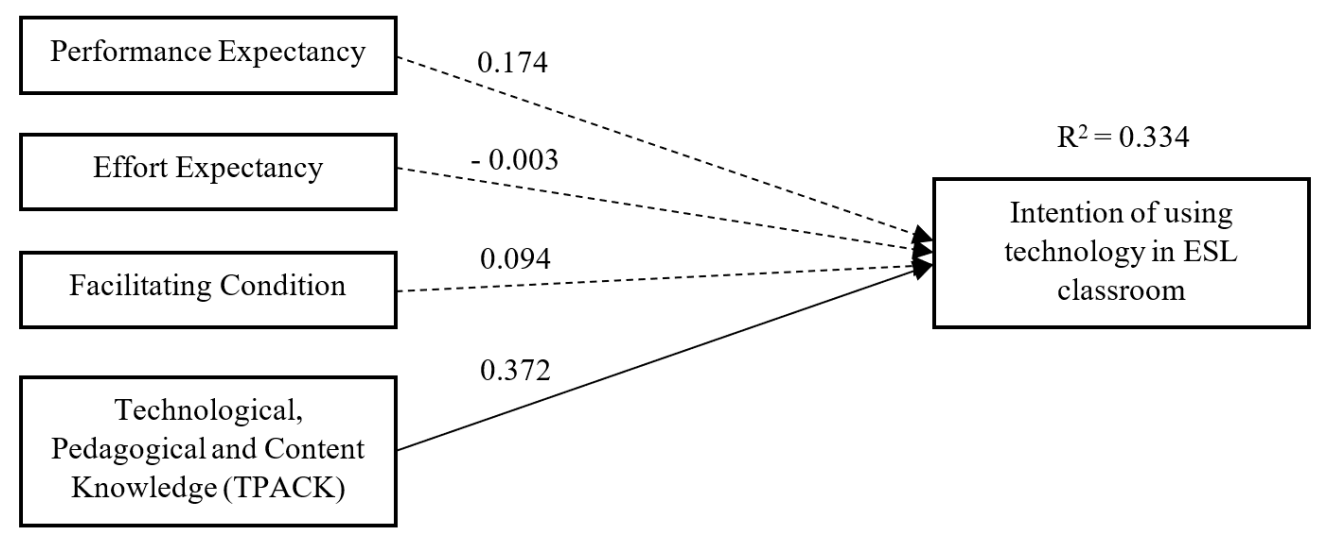

Figure 6. Factor affecting intention for using technology in the ESL classroom $(p<0.10)$.

To conclude, TPACK is important in pre-service teachers' utilisation of technology in classrooms. Therefore, many teacher preparation programmes emphasise on preparing pre-service teachers to integrate technology with instruction in meaningful ways that support students' learning on the basis of the TPACK framework. In order to help preservice teachers to have better understanding of the connections between their content areas, content-specific pedagogies, and technologies, more exemplary TPACK lessons and experiences are needed [43]. It is important to provide more support and monitoring to pre-service teachers in TPACK during their field practices.

\section{Conclusions}

This study tested a conceptual model by examining the factors affecting Malaysian ESL pre-service teachers' intention to utilise technology in the classroom through a user acceptance model, which is Unified Theory of Acceptance and Use of Technology (UTAUT) by [24], with some modifications to the model. If teachers fail to accept the learning of technological tools offered to them, then they would not use them to enhance teaching of English language. Thus, this study provides teacher training institutions, especially in producing TESL teachers to make effective fiscal and educational decisions regarding technology usage in the ESL classroom in a globally competitive environment. Although technology usage is capable of offering new pedagogical approach, pre- service teacher's preferences are not sophisticated. This suggests that providing more technological friendly learning activities and resources could be the first step to incorporate technology in the ESL classroom, but educators need to eventually explore more instructional models that employ unique capabilities of educational technological tools for the purpose of teaching and learning English language. To educate pre-service teachers on benefits of incorporating technology in the classroom, support staff can help them be familiarised with using technological tools to access English language teaching resources, create various learning tasks, and provide recommendations for applications that support English language teaching by using technology. The key is to understand teachers' needs and factors impacting teachers' intention for using technology in the classroom. Overall, technological, pedagogical, and content knowledge (TPACK) is the only significant predictor of Malaysian ESL pre-service teachers' intention for using technology in the ESL classroom. Apparently, the implication on the ESL pre-service teachers is that they need to be trained to use technology more effectively so that different teaching approaches and learning needs could be accommodated effectively.

Author Contributions: All authors contributed to several aspects of the study, specifically, conceptualization, H.H.; methodology, L.L.W. and H.H.; formal analysis, investigation, resources and data curation, L.L.W. and H.H; writing-original draft preparation, L.L.W.; review and editing, L.L.W. and H.H; supervision, H.H. All authors have read and agreed to the published version of the manuscript. 
Funding: This research was funded by Universiti Kebangsaan Malaysia under research grant number GG-2020-027 and the APC was funded by Universiti Kebangsaan Malaysia.

Institutional Review Board Statement: Not applicable.

Informed Consent Statement: Informed consent was obtained from all subjects involved in this study.

Data Availability Statement: Data sharing not applicable.

Acknowledgments: The authors would like to acknowledge the contribution and the cooperation given by the respondents and institutions involved in this study.

Conflicts of Interest: The authors declare no conflict of interest.

\section{References}

1. Abunowara, A.M. Using technology in EFL/ESL classroom. Int. J. Hum. Cult. Stud. IJHCS 2016, 1, 7-23.

2. Dudeny, G.; Hocky, N. How to teach English with Technology; Pearson Longman: London, UK, 2007.

3. Baek, Y.; Jung, J.; Kim, B. What makes teachers use technology in the classroom? Exploring the factors affecting facilitation of technology with a Korean sample. Comput. Educ. 2008, 50, 224-234. [CrossRef]

4. Lubis, M.A.; Ariffin, S.R.; Muhamad, T.A.; Ibrahim, M.S.; Wekke, I.S. The integration of ICT in the teaching and learning processes: A study on smart school of Malaysia. In Proceedings of the 5th WSEAS/IASME International Conference on Education Technology, Canary Islands, Spain, 1-3 July 2009; pp. 189-197.

5. Ahmadi, M.R. The Use of Technology in English Language Learning: A Literature Review. Int. J. Res. Engl. Educ. 2018, 3, 115-125. [CrossRef]

6. Alsaleem, B.I.A. The Effect of "WhatsApp" Electronic Dialogue Journaling on Improving Writing Vocabulary Word Choice and Voice of EFL Undergraduate Saudi Students. Arab. World Engl. J. 2013, 4, 13.

7. Nomass, B.B. The Impact of Using Technology in Teaching English as a Second Language. Engl. Lang. Lit. Stud. $2013,3,111$.

8. Milton, P. Trends in the Integration of ICT and Learning in K-12 Systems. 2003. Available online: http://www.cea-ace.ca/ publication/trends-integration-ict-and-learning-k-12-systems (accessed on 30 June 2021).

9. Yüksel, G.; Kavanoz, S. In search of pre-service EFL certificate teachers' attitudes towards technology. Procedia Comput. Sci. 2011, 3, 666-671. [CrossRef]

10. Hashim, Y. The Evolution of Instructional Technology in Malaysia. Int. J. Instr. Media 2010, 37, 11.

11. Arifah. Study on the Use of Technology in ELT classroom: Teachers' Perspective; BRAC University: Dhaka, Bangladesh, 2014.

12. Lin, W.; Yang, S. Exploring students' perceptions of integrating Wiki technology and peer feedback into English writing courses. Engl. Teach. Pract. Critique 2011, 10, 88-103.

13. Sidupa, C.; Luke, J.; Kurniawan, C. The Role of ICT in Improving English Reading Ability: Case Study of 5th Semester University Students. In Proceedings of the 2nd International Conference on E-Society, E-Education and E-Technology-ICSET, Taipei, Taiwan, 13-15 August 2018; ACM Press: New York, NY, USA, 2018; pp. 42-45.

14. Romaña Correa, Y. Skype ${ }^{\mathrm{TM}}$ Conference Calls: A Way to Promote Speaking Skills in the Teaching and Learning of English. PROFILE Issues Teach. Prof. Dev. 2015, 17, 143-156. [CrossRef]

15. Godzicki, L.; Godzicki, N.; Krofel, M.; Michaels, R. Increasing Motivation and Engagement in Elementary and Middle School Students through Technology-Supported Learning Environments; Saint Xavier University: Chicago, IL, USA, 2013; p. 144.

16. Al-Ruz, J.A.; Khasawneh, S. Jordanian Pre-Service Teachers' and Technology Integration: A Human Resource Development Approach. J. Educ. Technol. Soc. 2011, 14, 77-87.

17. Velazquez-Torres, N. How well Are ESL Teachers Being Prepared to Integrate Technology in Their Classrooms? Tesl-EJ 2006, 9, n4.

18. Wachira, P.; Keengwe, J. Technology Integration Barriers: Urban School Mathematics Teachers Perspectives. J. Sci. Educ. Technol. 2011, 20, 17-25. [CrossRef]

19. Mishra, P.; Koehler, M.J. Technological Pedagogical Content Knowledge: A Framework for Teacher Knowledge. Teach. Coll. Rec. 2006, 108, 1017-1054. [CrossRef]

20. Venkatesh, V.; Davis, G.B. User Acceptance of Information Technology: Toward a Unified View. MIS Q. 2003, 27, 425. [CrossRef]

21. Betancourt-Odio, M.A.; Sartor-Harada, A.; Ulloa-Guerra, O.; Azevedo-Gomes, J. Self-perceptions on digital competences for m-learning and education sustainability: A study with teachers from different countries. Sustainability 2021, 13, 343. [CrossRef]

22. Nasr, N. Teachers as Students. Electron. J. Res. Sci. Math. Educ. 2020, 24, 168-171.

23. Leyton-Román, M.; González-Vélez, J.J.L.; Batista, M.; Jiménez-Castuera, R. Predictive Model for Amotivation and Discipline in Physical Education Students Based on Teaching-Learning Styles. Sustainability 2021, 13, 187. [CrossRef]

24. Liu, S.-H. A Multivariate Model of Factors Influencing Technology Use by Pre-service Teachers during Practice Teaching. Educ. Technol. Soc. 2012, 15, 13.

25. Batane, T.; Ngwako, A. Technology use by pre-service teachers during teaching practice: Are new teachers embracing technology right away in their first teaching experience? Australas. J. Educ. Technol. 2016, 33, 48-61. [CrossRef]

26. Farjon, D.; Smits, A.; Voogt, J. Technology integration of pre-service teachers explained by attitudes and beliefs, competency, access, and experience. Comput. Educ. 2019, 130, 81-93. [CrossRef] 
27. Hoxha, M.; Tafani, V.; Kennetz, K. Challenges and Impact of Teaching English in Limited Access to Technology Environment. In Proceedings of the MIT LINC 2019 Conference, Cambridge, MA, USA, 18-20 June 2019; Volume 3, pp. 152-161.

28. Singh, T.K.R.; Subramaniam, S.V. Pre-service Teachers' ICT Literacy: A Case Study in a Malaysian Teachers' Training Institution. Glob. J. Interdiscip. Soc. Sci. 2014, 3, 7.

29. Burden, K.; Hopkins, P. Barriers and Challenges Facing Pre-Service Teachers use of Mobile Technologies for Teaching and Learning. Int. J. Mob. Blended Learn. 2016, 8, 1-20. [CrossRef]

30. Kaba, B.; Touré, B. Understanding information and communication technology behavioral intention to use: Applying the UTAUT model to social networking site adoption by young people in a least developed country. J. Assoc. Inf. Sci. Technol. 2014, 65, 1662-1674. [CrossRef]

31. Teo, T.; Noyes, J. Explaining the intention to use technology among pre-service teachers: A multi-group analysis of the Unified Theory of Acceptance and Use of Technology. Interact. Learn. Environ. 2014, 22, 51-66. [CrossRef]

32. Holzmann, P.; Schwarz, E.J.; Audretsch, D.B. Understanding the determinants of novel technology adoption among teachers: The case of 3D printing. J. Technol. Transf. 2020, 45, 259-275. [CrossRef]

33. Aypay, A.; Sever, M. Technology Acceptance in Education: A Study of Pre-service Teachers in Turkey. Turk. Online J. Educ. Technol. 2012, 11, 264-272.

34. Baran, E.; Bilici, S.C.; Sari, A.A.; Tondeur, J. Investigating the impact of teacher education strategies on pre-service teachers' TPACK. Br. J. Educ. Technol. 2019, 50, 357-370. [CrossRef]

35. So, H.J.; Kim, B. Learning about problem-based learning: Student teachers integrating technology, pedagogy and content knowledge. Australas. J. Educ. Technol. 2009, 25, 101-116. [CrossRef]

36. Mohd Razali, N.N.F. The Importance and Efforts in Using Technology to Improve Language Teaching and Learning and The Teacher's Readiness for Integrating ICT in the Classroom in Malaysian Education. J. Educ. Soc. Sci. 2016, 5, $227-230$.

37. Johnson, A.M.; Jacovina, M.E.; Russell, D.G.; Soto, C.M. Challenges and Solutions when Using Technologies in the Classroom; Taylor and Francis: New York, NY, USA, 2016.

38. Mahmood, F.; Halim, H.A.; Rajindra, S.; Ghani, M. Factors Affecting Teachers Utilization of Technology in Malaysian ESL Classrooms. Malays. Online J. Educ. Technol. 2014, 2, 15-23.

39. Ursachi, G.; Horodnic, I.A.; Zait, A. How Reliable are Measurement Scales? External Factors with Indirect Influence on Reliability Estimators. Procedia Econ. Financ. 2015, 20, 679-686. [CrossRef]

40. Dexter, S.L.; Anderson, R.E.; Becker, H.J. Teachers' Views of Computers as Catalysts for Changes in Their Teaching Practice. J. Res. Comput. Educ. 1999, 31, 221-239. [CrossRef]

41. Korkmaz, G.; Toraman, Ç. Are We Ready for the Post-COVID-19 Educational Practice? An Investigation into What Educators Think as to Online Learning. Int. J. Technol. Educ. Sci. 2020, 4, 293-309. [CrossRef]

42. Naguib, G.H.; Alyamani, I.; Alnowaiser, A.M.; Hamed, M.T. Social Media Usage and Self-Perception among Dental Students at King Abdulaziz University, Saudi Arabia. J. Med Educ. 2018, 17, 11.

43. Tondeur, J.; Scherer, R.; Siddiq, F.; Baran, E. Enhancing pre-service teachers' technological pedagogical content knowledge (TPACK): A mixed-method study. Educ. Technol. Res. Dev. 2020, 68, 319-343. [CrossRef] 